\title{
TORREFIED BRIQUETTES OF SUGAR CANE BAGASSE AND EUCALYPTUS ${ }^{1}$
}

\author{
Emylle Veloso Santos Costa ${ }^{2 *}$ (D), Matheus Perdigão de Castro Freitas Pereira ${ }^{3}$, Carlos Miguel Simões \\ da Silva ${ }^{4}\left({ }^{0}\right.$, Bárbara Luísa Corradi Pereira $^{5}{ }^{\circ}$, Maria Fernanda Vieira Rocha ${ }^{6}$ and Angélica de Cássia \\ Oliveira Carneiro ${ }^{7}$
}

\footnotetext{
${ }^{1}$ Received on 03.12.2015 accepted for publication on 21.06.2017.

${ }^{2}$ Universidade Federal de Lavras, Programa de Pós-Graduação em Ciência e Tecnologia da Madeira, Lavras, Minas GeraisBrasil.E-mail: <emylleveloso@yahoo.com.br>

${ }^{3}$ Universidade Federal de Viçosa, Graduado em Ciência Florestal, Viçosa, Minas Gerais-Brasil .E-mail: <matheus.perdigao@live.com>

${ }^{4}$ Universidade Federal de Viçosa, Programa de Pós-Graduação em Ciência Florestal, Viçosa, Minas Gerais - Brasil . E-mail:

$<$ karmiguel@yahoo.com.br>

${ }^{5}$ Universidade Federal de Mato Grosso, Faculdade de Engenharia Florestal, Cuiabá, MT - Brasil. E-mail: <babicorradi@gmail.com>

${ }^{6}$ Universidade Federal de Lavras, Graduado em Ciência e Tecnologia da Madeira, Lavras, Minas Gerais - Brasil. E-mail: $<$ mfvrocha@yahoo.com.br>

${ }^{7}$ Universidade Federal de Viçosa, Departamento de Engenharia Florestal, Viçosa, Minas Gerais, Brasil. E-mail: <cassiacarneiro1@gmail.com> *Corresponding author.
}

\begin{abstract}
Torrefaction and briquetting are two techniques that improve the quality of the biomass and facilitate direct use as fuel. The objective was to evaluate the effect of torrefaction temperature on the properties of the compound briquettes made from sugar cane bagasse and Eucalyptus sawdust. After sample preparation and particle analyses, briquettes were produced with the mixture of the two biomasses, a total of five compositions $(0,25,50,75$ and $100 \%)$ at $120^{\circ} \mathrm{C}$ and pressure of 1500 PSI. Subsequently, the briquettes were torrefied at temperatures of 180,220 and $260^{\circ} \mathrm{C}$, for a period of 15 minutes. According to the results, both biomasses of Eucalyptus sawdust and sugar cane bagasse showed potential for the production of briquettes. The torrefaction reduced hygroscopicity and increased the calorific value of compound briquettes. The ideal composition for the production of briquettes is $100 \%$ Eucalyptus. The composition of $50 \%$ Eucalyptus $+50 \%$ sugar cane bagasse is also a great option, as some bagasse parameters were excellent. $260^{\circ} \mathrm{C}$ was the best temperature to promote energy savings.
\end{abstract}

Keywords: Biomass; Briquetting; Torrefaction.

\section{BRIQUETES TORRIFICADOS DE BAGAÇO DE CANA-DE-AÇÚCAR E EUCALIPTO}

\begin{abstract}
RESUMO - A torrefação e a briquetagem são duas técnicas que melhoram a qualidade da biomassa e facilitam seu uso direto como combustivel. O objetivo do trabalho foi avaliar o efeito da temperatura de torrefação nas propriedades dos briquetes compostos produzidos com bagaço de cana-de-açúcar e serragem de eucalipto. Após o preparo das amostras e análises das partículas, produziram-se briquetes com a mistura das duas biomassas, totalizando cinco composições (0, 25, 50, 75 e 100\%), na temperatura de $120^{\circ} \mathrm{C}$ e pressão de 1500 PSI. Posteriormente, realizou-se a torrefação dos briquetes nas temperaturas de 180, 220 e $260^{\circ}$, por um periodo de 15 minutos. De acordo com os resultados, tanto as biomassas de serragem de eucalipto como a de bagaço de cana apresentaram potencial para produção de briquetes. A torrefação reduziu a higroscopicidade e aumentou o poder calorifico dos briquetes compostos. A composição ideal para a produção de briquetes é a de $100 \%$ eucalipto. A composição de $50 \%$ eucalipto $+50 \%$ bagaço de cana também é uma ótima opção, já que alguns parâmetros do bagaço se sobressaíram. A temperatura de $260^{\circ} \mathrm{C}$ foi a que promoveu melhores ganhos energéticos.
\end{abstract}

Palavras-Chave: Biomassa; Briquetagem; Torrefação 


\section{INTRODUCTION}

Sugar cane bagasse has been widely used for energy generation. Amongst the domestic energy alternatives in Brazil, biomass from sugar cane bagasse accounts for $16.1 \%$ (Ben, 2014). The state of São Paulo is the largest producer of sugar cane with a planted area of $51.43 \%$ (Conab, 2014).

Eucalyptus wood has also contributed to optimizing the Brazilian energy matrix. This is because Eucalyptus has elevated volumetric growth, allowing propagation of vegetation, adaptable to diverse environmental conditions with wide acceptance on the economic market. Eucalyptus plantations represent $71.9 \%$ of the total planting in Brazil, with 25.2\% located in Minas Gerais, $17.6 \%$ in São Paulo and $14.5 \%$ in Mato Grosso do Sul (IBÁ, 2015).

Despite these two biomasses being widely used for energy, some properties can limit their direct use as fuel, such as their low density, low homogeneity and low calorific value. Therefore, so that the biomass can have a better energy quality, greater added economic value and ease of transportation and storage, the techniques of torrefaction and briquetting have been used (Kaliyan and Morey, 2009).

Torrefaction is a thermal treatment process with low energy demands. Temperatures between $200^{\circ} \mathrm{C}$ and $300^{\circ} \mathrm{C}$ with a low heating rate are used, in environments with minimal or even absent concentrations of oxygen or inert, and different permanent time (Felfli, 2004; Santos, 2012; Dutta and Leon, 2012). Torrefaction results in biomass with greater calorific value, greater homogeneity, greater dimensional stability, lower hygroscopicity and that is more resistant to breakdown (Dutta and Leon, 2012; Lora et al., 2013). During the briquetting process, the particulate matter is compressed to compact it into blocks in a defined form, with a lower volume and greater density, adding agglutinates or not. Using this energy concentration process, the biomass can be converted into a briquette, a material of greater commercial value (Antunes, 2000). Therefore, combining the technique of briquetting and torrefaction is ideal to produce better quality biomass, making it more competitive in comparison with other energy sources.

A way of further improving the characteristics of the briquettes is through the production of compound briquettes. This consists of a mixture of different biomasses and has the advantage of generating a final product

Revista Árvore. 2019;43(1):e430101 with low ash levels, lower sulfur quantities and a reduction in the emission of polluting gases during combustion, as well as balancing the densities of each material. The main aspect in producing compound briquettes is to avoid the dependence on just one raw material (Rodrigues et al., 2002).

Given the foregoing, this study seeks to evaluate the effect of the torrefaction temperature on the properties of the compound briquettes produced with sugar cane bagasse and Eucalyptus sawdust.

\section{MATERIALAND METHODS}

\subsection{Obtainment and preparation of raw material}

Sugar cane bagasse residues (Saccharun officinarum L.) from the variety UFV/RIDESA RB867515 were obtained from the Sugar cane Research and Experimentation Center at the Department of Phytotechnics at the Universidade Federal de Viçosa (UFV), Ponte nova, MG. We acquired Eucalyptus sp., wood chips with 5.5 years of age from commercial plantations, located in the state of Maranhão.

To obtain the particles for briquette production, the two materials were processed in a hammer mill with a $2 \mathrm{~mm}$ mesh. Following this, the particles were sorted using a $2 \mathrm{~mm}$ sieve, collecting the fraction that passed through to diminish the presence of fine particles, which might compromise subsequent analysis.

\subsection{Briquette production}

Starting from the lowest density material, sugar cane bagasse with a bulk density of $95 \mathrm{~kg} . \mathrm{m}^{-3}$, the particle mass necessary to promote better compaction of the briquettes was verified, being $16 \mathrm{~g}$ of particles per briquette. Based on this, we produced briquettes composed of two biomasses, Eucalyptus sawdust and sugar cane bagasse, with five compositions $(0,25,50$, 75 and $100 \%$ ), 7 replications and 28 briquettes for each composition, totaling 140 briquettes.

The briquettes were produced in a laboratory briquetting machine. The briquetting parameters of were: temperature of $120^{\circ} \mathrm{C}$, pressure of $1500 \mathrm{PSI}$, cooling and compression times of 8 minutes each, totaling 16 minutes for each briquette composition. The ideal conditions were defined based on preliminary experiments, to obtain briquettes without cracks or fissures. The average humidity used for the production

\author{
Revista Arvore. 2019;43(1):e430101
}


of briquettes was $8 \%$ for the sugar cane bagasse and $13 \%$ for Eucalyptus.

\subsection{Briquette torrefaction}

The briquettes were dried to $0 \%$ moisture in a hothouse with air circulation and a temperature of $105 \pm 2{ }^{\circ} \mathrm{C}$. The torrefaction took place in a laboratory muffle. The briquettes were placed on a metal tray, which was in turn placed in a stainless steel container installed inside the muffle, to avoid the entry of oxygen.

The temperatures (treatments) used for torrefaction of the briquettes were 180,220 and $260^{\circ} \mathrm{C}$, with 7 replications for each composition for each treatment, totaling 28 briquettes for each temperature. The torrefaction time was 15 minutes, counted after reaching the final established temperature.

\subsection{Particle properties in natura and of torrefied briquettes}

Bulk density was realized using a wooden container with the dimensions of $1 \times 1 \times 1$ (volume of $1 \mathrm{~m}^{3}$ ). The methodology described by EN 15103 (DIN, 2010) was employed.

The briquettes were immersed in mercury and the displaced volume was obtained by the variation of the weight created by the submersion. The apparent density was determined by dividing the briquette weight by its volume and then multiplying by the density of the mercury $13.456 \mathrm{~g} / \mathrm{cm}^{3}$.

The determination of the volatile constituents, ash and fixed carbon levels followed the procedures described in the norm NBR 8112 (ABNT, 1986).

The Gross Calorific Value (GCV) was determined following the norm NBR 8633 (ABNT, 1984), using an adiabatic calorimetric pump.

The hygroscopic equilibrium moisture (HEM) was determined after the biomass particles and the briquettes had been placed in a climatic chamber, at a temperature of $23^{\circ} \mathrm{C}$ and relative air humidity of $65 \%$ until reaching constant mass. The moisture was calculated according to the norm NBR 9484 (ABNT, 1986).

The energy density of the particles of the Eucalyptus and sugar cane bagasse biomasses was obtained by multiplying the net calorific value (NCV) by the granule density of each one. The NCV and ICV were determined, following Brito (1993), by the formulas: (i) $\mathrm{NCV}=[\operatorname{ICV}(1-\mathrm{u})]-(600 \mathrm{u})$

(ii) $\mathrm{IVC}=\mathrm{SCV}-[600(9 \mathrm{H} / 100)]$

With $\mathrm{H}$ - Hydrogen (\%); m - Moisture; ICV Inferior Calorific Value (Kcal/kg);

The hydrogen level considered for the two biomasses was the average of the values encountered in the literature, the value being equal to $6.0 \%$ (Paula et al., 2011; Macêdo, 2012). For the moisture, the value of $20 \%$ was adopted, which is that commercially utilized for these biomasses.

The energy density of the torrefied briquettes was calculated multiplying the net calorific value (NCV) by the apparent density of each composition submitted to each treatment. To obtain the NCV and ICV, the formulas mentioned above were used, however, the moisture $(\mathrm{m})$ considered for the samples was the average of the values obtained for the hygroscopic equilibrium moisture (HEM) (Table 2) for each composition submitted to each treatment.

\subsection{Statistical analysis of the data}

The experiment was performed according to a completely randomized design with 5 compositions $(0,25,50,75$ and $100 \%)$ and four torrefaction temperatures (control, $180^{\circ} \mathrm{C}, 220^{\circ} \mathrm{C}$ and $260^{\circ} \mathrm{C}$ ), with 7 replications (briquettes), totaling 28 treatments and 140 samples. The data was interpreted with the aid of analysis of variance (ANOVA). When significant differences were observed between the treatments, the averages were compared using the Tukey test, at $5 \%$ significance and $95 \%$ probability. The analyses were realized using the Statistica 7.0 software.

\section{RESULTS}

\subsection{Biomass properties in natura}

In the immediate chemical analysis, only the ash level presented significant differences between the biomasses, with the sugar cane bagasse having a greater percentage of inorganics with $1.30 \%$ in comparison with $0.12 \%$ for the Eucalyptus sawdust (Table 1).

It was observed that the hygroscopic equilibrium moisture, bulk density, gross calorific value and energy density of the Eucalyptus sawdust particles were greater than for the sugar cane bagasse (Table 1). 
Table 1 - Mean values of the properties of biomass sugar cane bagasse and Eucalyptus sawdust.

Tabela 1 - Valores médios das propriedades das biomassas bagaço de cana e serragem de eucalipto.

\begin{tabular}{ccc}
\hline Parameters & Sugar cane bagasse & Eucalyptus sawdust \\
\hline Content of volatiles (\%) & $86,25 \mathrm{a}$ & $86,50 \mathrm{a}$ \\
Fixed carbon (\%) & $12,44 \mathrm{a}$ & $13,39 \mathrm{a}$ \\
Ashes (\%) & $1,30 \mathrm{a}$ & $0,12 \mathrm{~b}$ \\
\hline Hygroscopic equilibrium moisture (\%) & $6,83 \mathrm{~b}$ & $10,09 \mathrm{a}$ \\
Bulk density $\left(\mathrm{kg} . \mathrm{m}^{-3}\right)$ & $95,0 \mathrm{~b}$ & $233,3 \mathrm{a}$ \\
Gross calorific value $\left(\mathrm{kcal}^{-1} \mathrm{~kg}^{-1}\right)$ & $4473 \mathrm{~b}$ & $4659 \mathrm{a}$ \\
Energetic density $\left(\mathrm{GJ} . \mathrm{m}^{-3}\right)$ & $1,27 \mathrm{~b}$ & 3,26 a \\
\hline
\end{tabular}

Mean values in lines followed by the same letter do not differ significantly by Tukey test at $5 \%$ probability.

\subsection{Properties of the torrefied briquettes}

Analysis of variance indicated that the evaluated parameters were affected by the treatments, however, there were no significant interactions between the torrefaction temperature and the biomass compositions, only the isolated effects of the treatments.

The volatile constituent levels varied by around $1.33 \%$ between the compositions of the biomasses. The composition of $75 \%$ Eucalyptus $+25 \%$ bagasse resulted in a greater average value for volatiles. Regarding the effect of the torrefaction temperature, it was observed that, generally with an increase in temperature, the percentage of volatiles was reduced, despite a significant difference being observed only at a temperature of $260^{\circ} \mathrm{C}$ (Table 2).

Generally, there was a reduction in the level of fixed carbon with an increase in the quantity of bagasse in the composition of the briquettes. It was observed that the higher average value of fixed carbon was found in the $100 \%$ Eucalyptus composition (16.33\%). The composition of $100 \%$ bagasse led to a lower average value for fixed carbon $(13.39 \%)$. There was also an increase in the level of fixed carbon due to an increase in the torrefaction temperature, principally a $260^{\circ} \mathrm{C}$.

It was generally observed that hygroscopic equilibrium moisture diminished to the extent that the percentage of sugar cane bagasse increased, except the composition of $50 \%$ Eucalyptus $+50 \%$ bagasse, in which there was a non-significant increase of this moisture. In the process of torrefaction, the hygroscopic equilibrium moisture diminished with the temperature increase, with the lowest average value being observed at $260^{\circ} \mathrm{C}$, being $3.89 \%$ less in comparison to the control (Table 2).

The lowest apparent density was obtained for the briquettes produced only with bagasse despite there being no significant difference between the other compositions. In terms of the torrefaction temperature, we note with the increase of temperature, a reduction of the apparent density, with the control and the temperature of $180^{\circ} \mathrm{C}$ showing no difference.

Table 2 - Mean values of the properties of the torrefied briquettes depending on the compositions of biomass and torrefaction temperature.

Tabela 2 - Valores médios das propriedades dos briquetes torrificados em função das composições das biomassas e da temperatura de torrefação.

\begin{tabular}{|c|c|c|c|c|}
\hline Compositions & $\begin{array}{c}\text { Content of } \\
\text { volatiles } \\
(\%)\end{array}$ & $\begin{array}{c}\text { Fixed } \\
\text { carbon } \\
(\%)\end{array}$ & $\begin{array}{l}\text { Hygroscopic } \\
\text { equilibrium } \\
\text { moisture }(\%)\end{array}$ & $\begin{array}{c}\text { Apparent } \\
\text { density } \\
\left(\mathrm{kg} \cdot \mathrm{m}^{\mathbf{3}}\right)\end{array}$ \\
\hline $100 \%$ Eucalyptus & $83,60 \mathrm{ab}$ & $16,33 \mathrm{a}$ & 7,59 a & $1020 \mathrm{a}$ \\
\hline $75 \%$ Eucalyptus $+25 \%$ Bagasse & $84,75 \mathrm{a}$ & $14,95 \mathrm{~b}$ & $6,90 \mathrm{~b}$ & $1000 \mathrm{ab}$ \\
\hline $50 \%$ Eucalyptus $+50 \%$ Bagasse & $83,42 \mathrm{~b}$ & $15,25 \mathrm{ab}$ & $7,10 \mathrm{ab}$ & $1020 \mathrm{a}$ \\
\hline $25 \%$ Eucalyptus $+75 \%$ Bagasse & $83,75 \mathrm{ab}$ & $14,45 \mathrm{bc}$ & $6,84 \mathrm{~b}$ & $1000 \mathrm{ab}$ \\
\hline $100 \%$ Bagasse & $84,25 \mathrm{ab}$ & $13,39 \mathrm{c}$ & $6,52 \mathrm{~b}$ & $960 \mathrm{~b}$ \\
\hline \multicolumn{5}{|l|}{ Temperature $\left({ }^{\circ} \mathrm{C}\right)$} \\
\hline Control & $85,41 \mathrm{a}$ & $13,48 \mathrm{~b}$ & 8,16 a & $1050 \mathrm{a}$ \\
\hline 180 & 85,43 a & $13,42 \mathrm{~b}$ & 8,11 a & $1040 \mathrm{a}$ \\
\hline 220 & 84,95 a & $13,89 \mathrm{~b}$ & $7,42 \mathrm{~b}$ & $1000 \mathrm{~b}$ \\
\hline 260 & $80,02 \mathrm{~b}$ & $18,70 \mathrm{a}$ & $4,27 \mathrm{c}$ & $930 \mathrm{c}$ \\
\hline
\end{tabular}

Mean values in columns followed by the same letter do not differ significantly from each other by Tukey test at $5 \%$ probability.

Revista Árvore. 2019;43(1):e430101 


\subsubsection{Ash content}

The analysis of variance indicated that the ash content was only affected by the compositions of the biomasses. In terms of the torrefaction temperature, the ash content was statistically similar, with an average value of $1.36 \%$.

An increase in the average values for ash content was observed to the extent that cane bagasse was added to the composition with $100 \%$ bagasse having a higher ash content, differing statistically from the others. The compositions of $75 \%$ Eucalyptus $+25 \%$ bagasse and $50 \%$ Eucalyptus $+50 \%$ bagasse, presented statistically similar values (Table 3 ).

\subsubsection{Gross calorific value}

The analysis of variance indicated that the gross calorific value was affected by the treatments, with significant interactions between the torrefaction temperature and the compositions of the biomasses.

The average values of calorific value observed in this work had a variation of $519 \mathrm{kcal} \mathrm{kg}^{-1}$, around $11 \%$.

Generally, the average calorific values for the torrefied briquettes at the temperature of $260^{\circ} \mathrm{C}$ were superior to the others (Table 4).

Table 3 - Mean values of the ashes content of the briquettes depending to the compositions.

Tabela 3 - Valores médios do teor de cinzas dos briquetes em função das composições.

\begin{tabular}{cc}
\hline Compositions & Ashes content (\%) \\
\hline $100 \%$ Eucalyptus & $0,45 \mathrm{~d}$ \\
$75 \%$ Eucalyptus $+25 \%$ Bagasse & $0,98 \mathrm{c}$ \\
$50 \%$ Eucalyptus $+50 \%$ Bagasse & $1,08 \mathrm{c}$ \\
$25 \%$ Eucalyptus $+75 \%$ Bagasse & $1,78 \mathrm{~b}$ \\
$100 \%$ Bagasse & $2,52 \mathrm{a}$ \\
\hline
\end{tabular}

Mean values in columns followed by the same letter do not differ significantly from each other by Tukey test at $5 \%$ probability.
It was also observed that the calorific value of the different compositions presented a tendency to increase with an increase in torrefaction temperature. The briquettes without treatment (control) generally presented lower levels for calorific value in comparison to the briquettes that underwent the torrefaction process.

When analyzing the compositions, it was observed that there was a reduction in the average levels of calorific value to the extent that the quantity of sugar cane bagasse increased, with the gross calorific value (5003 kcal $\mathrm{kg}^{-3}$ ) being observed in the $100 \%$ Eucalyptus composition at $260^{\circ} \mathrm{C}$ (Table 4 ).

\subsubsection{Energy density}

Significant differences of energy density were not found between the torrefaction temperature and the biomass compositions of Eucalyptus and sugar cane bagasse, that is, all the treatments resulted in a similar energy density. The general average obtained was 17.06 GJ $\mathrm{m}^{-3}$ with a standard deviation of 0.84 .

\section{DISCUSSION}

\subsection{Biomass properties in natura}

Volatile constituents are responsible for a large part of the heat generated in combustion and in the combustible solids the level varied from 76 to $86 \%$ (Morais et al., 2004). According to Werther et al., (2000) percentages above $80 \%$ facilitated the ignition of the material as well as its burning. The level of volatiles found both in the sugar cane bagasse and in the Eucalyptus was around 86\%. Santos (2012) found values of $81.1 \%$ of volatile materials for both Eucalyptus and for sugar cane bagasse. Therefore, the values found in this study are satisfactory for the production of

Table 4 - Mean values of the gross calorific value $\left(\mathrm{kcal} \mathrm{kg}^{-1}\right)$ of the briquettes depending on the torrefaction temperature and compositions.

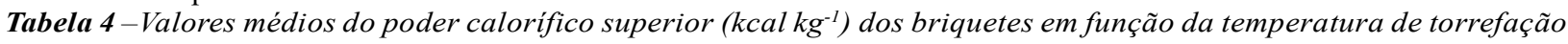
e das composições.

\begin{tabular}{|c|c|c|c|c|}
\hline \multirow[t]{2}{*}{ Compositions } & \multicolumn{4}{|c|}{ Temperature $\left({ }^{\circ} \mathrm{C}\right)$} \\
\hline & Control & 180 & 220 & 260 \\
\hline $100 \%$ Eucalyptus & $4802 \mathrm{aB}$ & $4715 \mathrm{aB}$ & 4865 aAB & $5003 \mathrm{aA}$ \\
\hline $75 \%$ Eucalyptus $+25 \%$ Bagasse & $4668 \mathrm{abB}$ & $4646 \mathrm{abB}$ & $4726 \mathrm{abB}$ & $4966 \mathrm{abA}$ \\
\hline $50 \%$ Eucalyptus $+50 \%$ Bagasse & $4624 \mathrm{bcB}$ & $4616 \mathrm{abB}$ & $4618 \mathrm{bB}$ & $4901 \mathrm{abA}$ \\
\hline $25 \%$ Eucalyptus $+75 \%$ Bagasse & $4549 \mathrm{bcB}$ & $4576 \mathrm{abB}$ & $4562 \mathrm{cB}$ & $4880 \mathrm{abA}$ \\
\hline $100 \%$ Bagasse & $4484 \mathrm{cB}$ & $4486 \mathrm{bB}$ & $4505 \mathrm{cB}$ & $4837 \mathrm{bA}$ \\
\hline
\end{tabular}

Mean values along the lines of the same lowercase letters for the composition and followed along the same column capitals to the temperature did not differ significantly from each other by the Tukey test at $5 \%$ probability. 
briquettes for energy use, given that the briquettes quickly start to combust.

The fixed carbon level refers to the fraction of the material that burns in the solid state, in the form of an incandescent coal that constitutes the final stage of combustion when the energy is slowly released. In the biomass in natura, the level of fixed carbon was similar for the Eucalyptus and bagasse particles. Vilas Boas (2011) studying the effect of the thermal treatment of the wood for the production of briquettes observed fixed carbon values for Eucalyptus particles in natura of $13.05 \%$.

The ash content is the important parameter for the lignocellulosic materials destined for energy generation, since its level negatively affects the calorific value and additionally can increase the frequency of cleaning of the ashtrays, the place where they are deposited. Therefore, the lower the ash content, the better for the briquetting process as is the case of the Eucalyptus sawdust. However, $1 \%$ of the ash is also considered a low value. According to Obernbergar and Thek (2010), ash levels greater than 3\% for wood are prejudicial in lignocellulosic fuels. Macêdo (2012) found values of $0.27 \%$ of ash for Eucalyptus. Paula et al., (2011), characterizing vegetable biomass for energy utilization, found ash levels for sugar cane bagasse of $0.80 \%$ and for wood residues they found a variation between 0.13 and $0.18 \%$. Both the ash values found in the literature for Eucalyptus and sugar cane bagasse are close to those obtained in this study.

Regarding the hygroscopic equilibrium moisture, the lower the level for the material in the environment in which it will be used, the lower the energy consumed to evaporate the water and the greater the efficiency of the equipment utilized to generate energy derived from the biomass. At the same time, the material can be stored for long periods without damaging its energy qualities. Therefore, the biomass of the sugar cane bagasse stands out.

The greater the bulk density, the smaller the space that will be occupied by the same quantity of material. The sugar cane bagasse was the least dense material. In this case, the importance of the briquetting mechanisms that transform the biomass into a compacted product is highlighted. Comparatively, the Eucalyptus sawdust achieved greater density. High density biomasses have little result in densification, not being attractive for

Revista Árvore. 2019;43(1):e430101 briquetting. Therefore, mixing materials with different densities, as was done in this study, is a way of resolving this question.

The gross calorific value (GCV) represents the quantity of energy freed by the dry mass aggregate. Therefore, the greater the calorific value, the better the material in energy terms. The greater SCV was obtained from Eucalyptus sawdust, due, probably to the greater level of fixed carbon and the lower ash content. According to Santo et al., (2011) ash content negatively affects the calorific value. For the production of briquettes, the ideal is biomass with a higher calorific value. Therefore, the lower quantity of material can be sufficient for a specific generation of energy.

A statistically greater energy density was observed for the Eucalyptus sawdust than that of the bagasse, with the elevated bulk density being responsible for this effect, despite the higher calorific value of the Eucalyptus also directly influencing the energy density.

\subsection{Properties of terrified briquettes}

It was already expected that the percentage of volatile constituents was reduced with the increase of torrefaction temperature. Rodrigues (2009) performed a study with Eucalyptus grandis wood with different thermal treatments and obtained a reduction in volatile constituents with the temperature increase, with the control having a value of $80.15 \%$ and for the temperature of $220^{\circ} \mathrm{C}, 79.32 \%$. A temperature of $260^{\circ} \mathrm{C}$ presented the best result for this parameter, given that the volatiles helped in the quicker volatilization of the raw material and through this, contributed to the biomass energy properties, as well as favoring the heterogeneous burning and reduction of the permanence of the material in the combustion equipment.

Given that the level of fixed carbon is a parameter inversely proportional to the level of volatiles, the lower values were observed in the compositions with a greater level of volatile constituents. The highest value found for the level of fixed carbon at the temperature of $260^{\circ} \mathrm{C}$ was due to the greater breakdown of the hemicellulose in this temperature bracket. Pereira et al., (2013) when studying the thermal breakdown of the wood in different Eucalyptus clones, found that breakdown of hemicellulose was included mainly in the bracket between 250 and $300^{\circ} \mathrm{C}$. These results are in agreement with Rodrigues (2009) and Vilas Boas (2011) who verified an increase 
in the level of fixed carbon according to the increase in torrefaction temperature.

The lower the equilibrium moisture of the biomass, the greater the quantity of energy by volume to be transported. Accepting this, the best composition for this context is $100 \%$ bagasse $(6.52 \%)$ followed by the composition with $25 \%$ Eucalyptus $+75 \%$ bagasse $(6.84 \%)$, though no statistical difference was observed between the two.

The torrefaction process reduced the hygroscopicity of the biomass, with lower hygroscopic equilibrium moisture at $260^{\circ} \mathrm{C}$, since to the extent that the torrefaction temperature increases, there is a reduction in the relations of the hydrophilic and hydrophobic constituents, with an increase in the lignin percentage and a reduction in the holocellulose percentage. According to studies realized by Mburu et al., (2007), regarding the effect of torrefaction on the physical-chemical properties of the wood, they observed that during the temperature increase there was a breakdown of more hydrophilic compounds (hemicelluloses) with a relative increase in the proportion of lignin, increasing the hydrophobic character of the material.

Vilas Boas (2011) observed, for the briquettes produced with Eucalyptus sp. particles with different thermal treatments, values for hygroscopic equilibrium moisture of $11.74,10.18$ and $10.72 \%$ for the control, $180^{\circ} \mathrm{C}$ and $220^{\circ} \mathrm{C}$, respectively. In the present study, lower values of $8.16,8.11$ and $7.42 \%$ were observed for the same torrefaction temperatures.

The apparent density of the briquettes defines the storage and transportation conditions, and directly affects energy density. All the compositions presented statistically similar apparent densities, since the compression pressure to produce the briquettes was constant, which led to the same degree of compression in both biomasses. Briquetting had the advantage of transforming low-density biomasses into a compressed final product, given that the compression reduced the volume of the material, as well as increasing the energy generated in comparison with the biomass in natura. For the pure briquettes, $100 \%$ Eucalyptus or $100 \%$ bagasse, there was a relevant increase in density when compared with the biomass in natura, which indicates the importance of the compression in the production of the briquettes.

The briquettes produced with sugar cane bagasse led to a lower apparent density, given that low density biomasses have a lower result in the compression when compressed with denser biomasses such as Eucalyptus sawdust.

The reduction of the apparent density with the increase of torrefaction temperature is related to the greater loss of mass that occurred at $260^{\circ} \mathrm{C}$.

\subsection{Ash content}

Given that the torrefaction temperature did not influence the ash content, probably such an outcome would be obtained with higher temperatures for the ash content to be significant. This is due to a greater breakdown of organic material, with only the inorganic fraction of the material, the ash, remaining. Higher temperatures also led to a greater loss of mass, which meant that the quantity of ash was more representative in terms of the total mass. Therefore, for not being significant, for the ash torrefaction at higher temperatures was advantageous.

The ideal is that the ash content be as low as possible, thereby favoring the process in energy terms, since there would be little influence on the calorific value of the material. The $100 \%$ Eucalyptus composition was the one which resulted in the lower average ash content, being more recommended for the production of briquettes, given that it helps in the increase of calorific value. By contrast, the $100 \%$ bagasse composition achieved the highest average ash content. This was due to the nature of bagasse itself, or could have been influenced by the origin of the material with impurities originating from soil residues.

\subsection{Gross calorific value}

We found that the torrefaction temperature has an influence on the increase of the fixed carbon level, which influenced the increase of the calorific value.

The $100 \%$ Eucalyptus composition at a temperature of $260^{\circ} \mathrm{C}$ led to a greater calorific value due to its elevated level of fixed carbon as well as the greater quantity of lignin and extractives.

Higher gross calorific values are highly desirable, given that a greater quantity of energy is released in the process by the biomass.

\subsection{Energy density}

Energy density is a parameter that indicates the quantity of energy by volume of the material, in this 
case, of the torrefied briquettes. The greater the energy density of the material, the lower the requirements for its transportation and storage.

The result obtained is probably due to the gross calorific values, hygroscopic equilibrium values and apparent density having been close in the treatment, frequently showing no statistical difference between one another. However, this does not mean that the compound and terrified briquettes did not show energy potential.

Rodrigues (2009) encountered energy density values for Eucalyptus for the control, 220 and $250^{\circ} \mathrm{C}$ of $16.60,16.92$ and $16.96 \mathrm{GJ} \mathrm{m}^{-3}$, respectively. These values are close to the average value obtained in the present study.

In terms of the biomasses in natura, there was an increase of $13.8 \mathrm{GJ} \mathrm{m}^{-3}$ in the energy density of torrefied briquettes, especially due to the greater apparent density. The compression of the sugar cane bagasse and Eucalyptus biomasses and consequently the lower volume, generated an accumulation of energy in the briquettes, meaning that there was an increase in potential energy.

\section{CONCLUSIONS}

Both the Eucalyptus sawdust biomass and the sugar cane bagasse biomass present potential for briquette production. The Eucalyptus sawdust stood out, presenting better chemical and physical properties.

The ideal composition for the production of briquettes is $100 \%$ Eucalyptus, since the results were better both for the properties of the biomass in natura and for the properties of the torrefied briquettes. The composition of $50 \%$ Eucalyptus $+50 \%$ sugar cane bagasse is also a good option, since in this manner we can make use of the advantages found in each one, given that some parameters in one stands out in comparison to the other and vice versa.

Torrefaction, generally, contributes to the energy potential of the compound briquettes, since it reduces its hygroscopicity and increases its calorific value.

The torrefaction temperature of $260^{\circ} \mathrm{C}$ promoted better energy gains given that it presented the highest levels of fixed carbon, calorific value and lowest hygroscopic equilibrium moisture.

\section{ACKNOWLEDGMENTS}

The authors thank to the support of FAPEMIG (Fundação de Amparo à Pesquisa do Estado de Minas Gerais), CNPq (Conselho Nacional de Desenvolvimento Científico e Tecnológico) and the technical support of Panels and Wood Energy Laboratory (LAPEM/DEF/ UFV).

\section{REFERENCES}

Associação Brasileira de Normas Técnicas ABNT. NBR 8112: Análise química imediata do carvão vegetal. Rio de Janeiro: 1986a.

Associação Brasileira de Normas Técnicas ABNT. NBR 8633: Determinação do poder calorífico superior. Rio de Janeiro: 1984.

Associação Brasileira de Normas Técnicas ABNT. NBR 9484: Compensado - Determinação do teor de umidade. Rio de Janeiro: 1986b.

Antunes RC. Briquetagem de carvão vegetal: Produção e utilização de carvão vegetal. Rev CETEC. 2000;1:197-206.

Brito JO. Expressão da produção florestal em unidades energéticas. In: Anais do $1^{\circ}$ Congresso Florestal Panamericano e $7^{\circ}$ Congresso Florestal Brasileiro, 1993, Curitiba. Curitiba: 1993. p.280-82.

Companhia Nacional de Abastecimento - CONAB. Acompanhamento da safra brasileira - Cana-deaçúcar. Segundo levantamento. Safra 2013-2014. Brasília: Conab/Ministério da Agricultura, Pecuária e Abastecimento; 2014.

Deutsches Institut fur Normung - DIN EN 15103 Solid biofuels determination of bulk density. Alemanha. 2010.

Dutta A, Leon MA. Pros and cons of torrefaction of woody biomass. University of Guelph; 2012.

Felfli FEF. Torrefação de biomassa: Viabilidade técnica e potencial de mercado [tese]. 2004. Campinas: Universidade Estadual de Campinas; 2003.

Indústria Brasileira de Árvores - IBÁ. Relatório IBÁ 2015. 2015.

Revista Árvore. 2019;43(1):e430101 
Kaliyan K, Morey RV. Factors affecting strength and durability of densified biomass products. Biomass and Bioenergy. 2009;33(3):337-59.

Lora EES, Venturini OJ, Andrade RV. Torrefação de madeira. In: Santos F, Colodette J, Queiroz JH, editors. Bioenergia \& Biorrefinaria - Cana-deaçúcar \& Espécies Florestais". Viçosa, MG: UFV; 2013. p.401-27.

Macêdo LA. Influência da composição da biomassa no rendimento em condensáveis do processo de torrefação [dissertação]. Brasília, DF: Faculdade de Tecnologia da Universidade de Brasília; 2012.

Mburu F, Dumarçay S, Petrissans M, Gérardin P. Evaluation of thermally modified Grevillea robusta heartwood as an alternative to shortage of wood resource in Kenya: characterisation of physicochemical properties and improvement of bioresistance. Bioresource Technology. 2007;98(18):3478-86.

Morais SAL, Nascimento EA, Melo DC. Análise da madeira Pinus oocarpa parte 1 - estudo dos constituintes macromoleculares e extrativos voláteis. Revista Árvore. 2004;29(3):461-70.

Obernberger I, Thek G. The pellet handbook: The production and thermal utilisation of pellets. London: Earthscan; 2010.

Paula LER, Trugilho PF, Rezendo RN, Assis CO, Baliza AER. Produção e avaliação de briquetes de resíduos lignocelulósicos. Revista Florestal Brasileira. 2011;31(66):103-12.
Pereira BLC, Carneiro ACO, Carvalho AMML, Trugilho PF, Melo ICNA, Oliveira AC. Estudo da degradação térmica da madeira de Eucalyptus através de termogravimetria e calorimetria. Revista Árvore. 2013;37(3):567-76.

Rodrigues LD, Silva IT, Rocha BRP, Silva IMO. Uso de briquetes compostos para produção de energia no estado do Pará. In: Anais do $4^{\circ}$ do Encontro Energético Meio Rural. 2002, Campinas. Campinas: AGRENER; 2002.

Rodrigues TO. Efeitos da torrificação no condicionamento de biomassa para fins energéticos [dissertação]. Brasília, DF: Universidade de Brasília; 2009.

Santos JRS. Estudo da biomassa torrada de resíduos florestais de eucalipto e de bagaço de cana-de-açúcar para fins energéticos [dissertação]. Piracicaba: Escola Superior de Agricultura “Luiz de Queiroz", Universidade de São Paulo; 2012.

Santos RC, Carneiro ACO, Castro AFM, Castro RVO, Bianche JJ, Souza MM, et al. Correlações entre os parâmetros de qualidade da madeira e do carvão vegetal de clones de eucalipto. Scientia Forestalis. 2011;39(90):221-30.

Vilas Boas MA. Efeito do tratamento térmico da madeira para produção de briquetes. Viçosa, MG: Universidade Federal de Viçosa; 2011.

Werther J, Saengera M, Hartgea EU, Ogada T, Siagib $Z$. Combustion of agricultural residues. Progress in Energy and Combustion Science. 2000;26:1-27. 